\title{
Self-actualization as a Factor of the Development of Students-Philologists' Readiness to Provide Professional Activities
}

\section{Самоактуалізація як чинник формування готовності студентів філологічних спеціальностей до виконання професійної діяльності}

Ernest Ivashkevych

Ph.D. in Psychology, Lecturer of the Department of English

Practice, Translator
Ернест Івашкевич

кандидат психологічних наук, викладач кафедри практики англійської мови, перекладач

E-mail:ivashkevych.ee@gmail.com https://orcid.org/0000-0001-7219-1086

Researcher ID: F-3865-2019 scopus.com

Rivne State University of the Humanities, Rivne, Ukraine 12, Stepana Bandery str., Rivne, 33000

\section{Ruslan Simko}

Ph.D. in Psychology, Senior Lecturer
Рівненський державний гуманітарний університет, м. Рівне, Україна вул. Степана Бандери, 12, м. Рівне, Україна, 33000

\section{Руслан Сімко}

кандидат психологічних наук, старший викладач

E-mail:7kort@ukr.net orcid.org/0000-0002-9147-9541

Researcher ID: F-2765-2019

Kamianets-Podilskyi National

Ivan Ohiienko University, Kamianets-Podilskyi, Ukraine 61, Ohiienka street, KamianetsPodilskyi, Khmelnytskyi region, 32300
Кам'янеиь-Подільський національний університет ілені Івана Огієнка, м. Кам'янеиь-

Подільський, Україна вул. Огієнка, 61 , м. Кам'янецьПодільський, Хмельницька обл., 32300 
Original manuscript received February 24, 2019

Revised manuscript accepted March 25, 2019

The author's contribution: E. Ivashkevych $-50 \%$, R. Simko $-50 \%$. Авторський внесок: Е. Івашкевич $-50 \%$, Р. Сімко - $50 \%$.

\section{ABSTRACT}

In this article the professional development of future translators is considered from the standpoint of the cultural approach. So, it is a process of forming the person's personal and professional position of the individual, taking into account the diversity of subjective and objective factors, which involve the implementation of strategies for managing the personal resources which are necessary for professional activities on the professional level. It was noted that the professional development of the future interpreter also involved the formation of personally significant position, which was understood by us as a system of dominant values-semantic attitudes of a specialist to the socio-cultural environment, of himself/herself and his / her activities.

According to the criteria of the professional development of future translators we mean a high level of readiness of students to perform translation activities, a high level of professional competence and translation consciousness.

Focusing on the answers of the most of the teachers, in the article we concluded that students of all higher educational establishments of foreign philology faculties had opportunities for becoming ready for professional activities, as well as these all teachers were ready to create an atmosphere that was individual for each student at classes.

Thus, three groups of teachers were distinguished for self-evaluation of their own activities according to their desire to create a creative atmosphere in the classroom. These are teachers with high self-esteem of their own professional activity, situational (average) and low self-esteem. It was noted that the representatives of the first group try to stimulate the self-actualization of the students as much as possible, their readiness for independent performance of the translation activity (such answers as "I try to stimulate the initiative of students", "there is always a desire to work in the atmosphere of freedom because of professional activity", "all my tasks in a great degree were involved into analytical and creative work that must be performed in their professional activity»). Representatives of the second group (with situational self-esteem) seek to stimulate students only according to the opportunities and extraor- 
dinary perseverance of the students (for example: "I encourage students to work independently, but they do not want to work individually in this group» or "the content of discipline, which I am teaching, is extremely difficult, therefore students simply can not work independently»). The third group included teachers with a low self-esteem of their own professional activities. The answers were typical for them: "There is not enough time for individualization of studies", "the course does not involve performing independent creative tasks», "students are not able to do this», "in the curriculums independent work occupies a separate place, the hours are not included into curriculums».

Key words: professional development, culturological approach, personal and professional position of the person, professional competence, translation consciousness, self-evaluation of the professional activity.

\section{Вступ}

Професійному становленню особистості в науковій літературі приділяється особлива увага, оскільки воно зумовлює самовизначення людини, її фахове й особистісне зростання, розуміння необхідності здійснення своєї професійної діяльності для суспільства і виконання останньої $з$ найповнішою реалізацією своїх здібностей і можливостей.

Як досить тривалий процес розвитку особистості, який починається із формування професійних намірів і триває до повної реалізації себе в професійній діяльності, розглядає «професійне становлення» Н. І. Пов’якель (Пов’ якель, 2003). У науковій царині центральною ланкою процесу професійного становлення вважається професійне самовизначення. Зокрема, Е. Ф. Зеєр (Зеєр, 2008) тлумачить «професійне становлення» як формоутворення особистості, адекватне вимогам виконання певної професійної діяльності. Професійне становлення особистості вчителя як процес розв'язання професійно значущих задач, які поетапно ускладнюються (ідеться, зокрема, про пізнавальні, морально-етичні й комунікативні задачі), розглядає Р. Хок (Хок, 2006). Так, учений зазначає, що саме у процесі розв'язання задач фахівець оволодіває потрібним комплексом умінь, пов'язаним із його професійною діяльністю, діловими і моральними якостями тощо. 
Сутність професійного становлення фахівця може бути описана у зіставленні її змісту з категоріями "розвиток» i «формування». Розвиток визначається як досить об’єктивний процес особистісного (кількісного і якісного) змінювання. Одночасна експлікація цих характеристик відрізняє розвиток від інших процесуальних змін. При цьому слід наголосити, що зворотні зміни характерні для процесів функціонування (тобто, ідеться про циклічне відтворення постійної системи зв'язків і взаємовідносин); за відсутності особистісної спрямованості зміни синтезуватимуться, що позбавляє процес особистісного розвитку внутрішньої цілісності та взаємоузгоджуваності його окремих компонентів. У свою чергу, будь-яке становлення, відповідно до філософії Гегеля, є основою всього подальшого розвитку особистості, початковою ланкою виникнення, породження та функціонування речей і явищ. На відміну від формування, становлення є постійно плинним процесом, який не має заданого кінцевого результату.

Більшість учених вважають, що професійне становлення є безкінечним процесом, який не має свого завершення. Він, на думку В. С. Біблера (Біблер, 1997), може раптово завершуватися та раптово продовжуватися, у тому числі в різні періоди часу, в різних просторах і культурах. Останнє наголошує на професійному становленні фахівця як на досить глобальному процесі професійного розвитку особистості, формуванні значущих для виконання фахової діяльності умінь і навичок, які водночас є надзвичайно важливими для існування глобального мультикультурного світу.

Професійне становлення особистості відбувається шляхом якісних змін, що фасилітують виникнення зовсім нового рівня її цілісності. Останнє передбачає якісну зміну характеристик особистості, перетворення вже сформованих, досить сталих настановлень, ціннісних орієнтацій, мотивів поведінки під впливом постійно змінюваних суспільних відносин. Також професійний розвиток особис- 
тості здійснюється внаслідок перебудови її спрямованості. Крім того, професійна спрямованість особистості є результатом суперечливого поєднання соціалізації, тобто опанування людиною соціально значущим досвідом і культурою, та індивідуалізації (процесу розвитку інтелекту, волі, естетичного смаку, творчих здібностей індивіда тощо). У процесі професійного становлення особистості відбувається i становлення її цілісності. На думку Н. Р. Битянової (Битянова, 1995), ця цілісність полягає у: 1) підпорядкуванні всіх елементів структури особистості її спрямованості, що забезпечує безперервність, наступність і поступальність усіх періодів її розвитку; 2) набутті необхідних профресійно значущих якостей, властивостей і характеристик.

Аналізуючи процес професійного становлення особистості, багато дослідників виокремлюють стадії, рівні, етапи, які проходить фахівець у своєму професійному зростанні. Зокрема, діяльнісний підхід до проблем профресійного становлення передбачає актуалізацію у фахівця базових характеристик особистісно-мотиваційної та операційнотехнічної сторін професійної діяльності. Оволодіння професійною майстерністю передбачає розвиток у фахівця знань, умінь і навичок, що формуються на основі професійно значущих здібностей, якими оволодіває людина у закладі вищої освіти (операційна сторона професійного становлення). Здібності особистості, що розвиваються в професійній діяльності, утворюють комплекс професійно важливих якостей, забезпечуючи передумови для подальшого особистісного розвитку фахівця, досягнення ним професійної майстерності. Професійні здібності, вважають Н. О. Михальчук і Л. Л. Примачок (Михальчук \& Примачок, 2019), є однією 3 найважливіших складових професійного становлення особистості; саме вони ніби «підштовхують» людину в підлітковому і юнацькому віці до вибору певної професійної сфери, надалі забезпечуючи успішне оволодіння фахівцем майбутньою спеціальністю. 
Розуміння особливостей професійного становлення, зазначає М. М. Філоненко (Філоненко, 2016), постає неможливим без вивчення змісту і структури мотивів особистості, що є основною фасилітативною силою вибору професії та прагнення щодо досягнення значущих для людини результатів у ній. Хід професійного становлення також безпосередньо пов'язаний із розвитком самосвідомості особистості. Адекватні знання про себе, свої можливості, здібності, ціннісні орієнтації дають змогу майбутньому фахівцеві обирати найдоцільніші для структури його особистості сфери професійної діяльності. Досягнуті у професії успіхи або невдачі, в свою чергу, коригують уявлення людини про себе, впливають на її самооцінку, рівень прагнень і самосвідомість загалом.

Професійне становлення, зазначає Е. 3. Івашкевич (Івашкевич, 2015), передбачає ще й активне включення людини в нове для неї соціальне середовище, яке характеризується своїми нормативами спілкування, поведінки, цінностями, стереотипами, моральними правилами й імперативами тощо. Міжособистісні взаємостосунки, що складаються в професійному колективі, багато в чому визначають хід професійної адаптації людини, формування їі соціального статусу. Тому до структури професійного становлення можуть бути включені й соціально-психологічні особливості людини, що визначають її місце у професійній групі, соціальний статус тощо.

Великою мірою значущі особливості професійного становлення виявляються у процесі знаходження людиною індивідуальних способів виконання професійної діяльності, що супроводжується формуванням у індивіда особистісно значущого (в тому числі - творчого) досвіду, професійної самосвідомості, системи професійних мотивів, особистісних смислів, значень і цілей. Аналіз наукових публікацій (Onufriieva, 2017), у яких так чи інакше розглядається проблема професійного становлення, свідчить про єдність думок дослідників стосовно того, що професій- 
не становлення є динамічним процесом перетворення (чи перебудови) особистісних і професійних якостей, який характеризується самовизначенням, самовдосконаленням, самоосвітою, самоактуалізацією, самореалізацією та власне формуванням своєї самосвідомості. Як бачимо, професійне становлення можна розглядати як досить тривалий у часі процес оволодіння професією.

Отже, аналіз наукової літератури свідчить про те, що процес професійного становлення може бути представлений двома способами: за схемою процесуального відтворення (як тимчасова послідовність ступенів, періодів, стадій) і за структурою професійної діяльності (як сукупність способів і засобів виконання професійної діяльності, коли їхнє дотримання має не тимчасову, а цільову детермінацію). Під професійним становленням також розуміють формування професійної компетентності як процес оволодіння засобами розв'язання професійних задач i завдань, а також опанування моделями прийняття професійно значущих рішень (О. Ф. Бондаренко, 1997; С. Д. Максименко, 2005; Онуфрієва, 2013; Onufriieva, 2017 та ін.).

Розглядаючи процес професійного становлення особистості як суб'єкта професійної діяльності та життєдіяльності, В. О. Сластьонін (Сластьонін, 1976) виокремлює кілька базових рівнів.

Адаптивний рівень професійного становлення. Цей рівень є так званою пристосовницькою стадією, яка свідчить про входження особистості до навчально-професійної діяльності. Зазначена стадія характеризується досить нестійким ставленням до сприйняття змісту професійної діяльності, адаптацією до нових життєвих соціокультурних реалій, нестійкою творчою активністю. На цьому етапі процес професійного становлення потребує: стимулювання різних форм експлікації самостійності й активності в професійно значущому середовищі; розвитку спеціальних, креативних, емпатійних здібностей; формування навичок самореалізації, самопізнання, емоційної саморегуляції; 
прийняття як особистісно значущих суб'єкт-суб'єктних стосунків, взаємодій у професійному середовищі; знаходження прямих i альтернативних способів розв'язання життєвих і професійних проблем; розвитку здатності до професійної інтерпретації життєвих обставин.

Професійно-репродуктивнолу рівню професійного становлення притаманні: розвиток потреби у здійсненні професійної діяльності; актуалізація пізнавальної рефлексії; оволодіння цінностями і смислами навчально-професійної діяльності; формування умінь створювати проекти майбутнього життєвого шляху (свого й інших людей); створення методологічної та методичної бази опанування фахівцем власною професією; розвиток професійного мислення, здатностей до реалізації професійних знань, умінь і навичок у практичній діяльності.

Третій рівень професійного становлення - особистісно-продуктивний - відрізняється тим, що фахівець набуває особистісного сенсу здійснення навчальної професійної діяльності. Це знаходить своє відображення у: розвитку регулятивних механізмів професійної діяльності, спілкування, творчості, самовираження майбутнього фахівця в навчально-виховному процесі; пошуку і стимулюванні набуття майбутнім фахівцем індивідуального стилю професійної діяльності; готовності до професійного розв'язання теоретико-прикладних, спеціально-виконавських i навчально-практичних проблем у вищих закладах освіти й у майбутній професійній діяльності; знаходженні індивідуальних шляхів адаптації до майбутньої професійної діяльності; становленні адекватної комунікативної поведінки майбутнього фахівця у професійній діяльності та впродовж свого життєвого шляху.

Наступний рівень професійного становлення - суб’ $\epsilon \kappa \mathrm{-}$ но-креативно-професійний рівень, що характеризується: суб'єктною реалізацією особистісно-професійного становлення фахівця; умінням здійснювати необхідну корекцію своєї професійної діяльності за допомогою самоаналізу; по- 
силенням ролі загальних і вузькоспеціальних знань в особистісному, життєвому і професійному планах; систематизацією поглядів і настановлень щодо своєї професії, соціокультурного простору, життєвого і професійного шляху; знаходженням свого власного індивідуального стилю виконання професійної діяльності; цілковитою готовністю до виконання професійної діяльності, експлікації у ній власних творчих досягнень, креативних продуктів і демонстрацією бажання до творчої репрезентації себе у майбутньому, до творчих звершень і досягнень тощо.

Крім того, В. О. Сластьонін (Сластьонін, 1976) пропонує модель професійного становлення майбутнього фахівця, розглядаючи її з позицій особистісного і профресійного саморозвитку, коли зовнішні педагогічні впливи збігатимуться з особистісним потенціалом людини. Це, з одного боку, означатиме цілковиту відповідність професійно значущих цілей, мотивів і способів реалізації професійних дій вимогам професії, а з іншого боку - не створює певних сталих меж для творчої реалізації фахівця. Відповідно, система професійно значущих вимог не приглушатиме, a, навпаки, ініціюватиме здатності фахівців до пошуку різних шляхів життєвого і професійного зростання, стимулюючи їхню активність, вибірковість, креативність, творчу спрямованість тощо (Онуфрієва, 2011).

Ми розглядатимемо професійне становлення майбутнього перекладача з позицій культурологічного підходу як процес формування особистісно-професійної позиції індивіда з урахуванням усього різноманіття суб'єктивних і об’єктивних чинників, що передбачає реалізацію стратегій управління особистісними ресурсами, потрібними для здійснення професійної діяльності на фаховому рівні. Професійне становлення майбутнього перекладача також передбачає формування особистісно значущої позиції, яка розуміється нами як система домінуючих ціннісно-смислових ставлень фахівця до соціокультурного оточення, самого себе і своєї діяльності. Так, порушена проблема є 
вельми актуальною і потребує проведення спеціальних досліджень, у тому числі - емпіричних.

Мета статті - розкрити особливості професійного становлення майбутнього фахівця й описати експериментальне дослідження з метою виявлення динаміки професійного становлення студентів філологічних спеціальностей.

\section{Завдання статті}

1. Виокремити критерії професійного становлення майбутніх перекладачів.

2. Проаналізувати відповіді викладачів на запитання інтерв'ю з метою визначення їхнього прагнення стимулювати самоактуалізацію та готовність студентів до виконання професійної діяльності.

3. Виокремити три групи викладачів за самооцінкою власної діяльності з огляду на їхнє бажання створити творчу атмосферу на заняттях, дати їх характеристику.

\section{Методи дослідження}

Експериментальне дослідження 3 метою виявлення динаміки професійного становлення майбутнього перекладача тривало упродовж 2016-2017 років. У ньому брали участь 303 студенти сформованих нами експериментальних і контрольних груп факультетів іноземної філології:

1) експериментальні групи (150 студентів):

- E1 - 38 студентів II курсу Рівненського державного гуманітарного університету;

- E2 - 40 студентів III курсу Львівського державного університету безпеки життєдіяльності;

- E3 - 35 студентів II курсу Східноєвропейського національного університету імені Лесі Українки;

- $\quad$ E4 - 37 студентів III курсу Кам’янець-Подільського національного університету імені Івана Огієнка;

2) контрольні групи (153 студенти):

- $\quad$ К1 - 39 студентів II курсу Рівненського державного гуманітарного університету; 
- $\quad$ К2 - 35 студентів III курсу Львівського державного університету безпеки життєдіяльності;

- $\quad$ К3 - 41 студент II курсу Східноєвропейського національного університету імені Лесі Українки;

- $\quad$ К4 - 38 студентів III курсу Кам'янець-Подільського національного університету імені Івана Огієнка.

Групи були сформовані за методом рандомізації (технологія парного дизайну). За критерії професійного становлення лиаибутніх перекладачів нами було прийнято високий рівень готовності студентів до виконання перекладацької діяльності, високий рівень сформованості професійної компетентності та перекладацької свідомості тощо.

Отже, на даному етапі дослідження ми вивчали рівень готовності майбутніх фахівців до виконання професійної діяльності. У якості методологічного інструментарію для першого етапу дослідження нами було обрано:

1) методику «Хто Я?» (Кун, Макпартленд, 2017);

2) техніки «Мій шлях у професію» та «Піраміда професійного зростання» (розроблені М. Ю. Варбан та О. Б. Старовойтенко й адаптовані нами для майбутніх перекладачів) (Варбан, 1998).

\section{Результати та дискусії}

Цей етап емпіричного дослідження був спрямований на оцінку готовності студентів до виконання професійної діяльності. Використання застосованих нами методик дало змогу виявити рівень сформованості у студентів мотиваційної, змістової, операційної та ціннісної готовності до виконання перекладацької діяльності.

Аналізуючи відповіді викладачів на запитання інтерв'ю, ми намагалися визначити їхні прагнення стимулювати самоактуалізацію та готовність студентів до виконання професійної діяльності. Ставлячи запитання викладачам: «Яке Ваше ставлення щодо готовності студентів до виконання перекладацької діяльності та прийняття ними самостійних рішень у процесі вивчення Вашого предме- 
та?», для нас було важливо визначити, чи створює викладач таку атмосферу на заняттях, яка стимулює студентів до виконання самостійної діяльності.

Питання було адресовано усім викладачам факультетів іноземної філології, які працювали в експериментальних і контрольних групах респондентів. Відповіді розподілились таким чином:

- найбільша кількість респондентів (48,24\%) відповіла, що «вважають індивідуальний підхід у викладанні основним і намагаються завжди його використовувати»;

- $15,63 \%$ стверджують, що вони «прагнуть до створення самостійної атмосфери на заняттях», але вважають, що «спочатку має бути досягнуто високого рівня розуміння матеріалу»;

- приблизно стільки ж відсотків викладачів $(14,01 \%)$ дали позитивну відповідь та уточнили, що «сам зміст дисципліни, яку вони викладають, передбачає здійснення індивідуального підходу» ;

- негативно відповіли 22,12\% викладачів, мотивуючи свою відповідь тим, що «під час викладання навчальних дисциплін існують часові обмеження, а обсяг обов' язкового для вивчення матеріалу не дозволяє їм «відступати» від заданої навчальної програми». Крім того, викладачами зазначалося, що, на жаль, студенти не мають такого запасу знань, який би дав їм змогу висловлювати свою думку з багатьох проблем або цікаво розв'язувати навчальні задачі.

Під час інтерв'ю викладачі окреслили такі причини, які, на їх думку, свідчать про відсутність творчої атмосфери на заняттях: «слабкі» студенти; відсутність мотивації до навчання; відсутність у студентів розуміння необхідності підготовки до певного навчального предмета; відсутність бажання працювати самостійно, творчо; відсутність ініціативи; відсутність потрібних знань.

Орієнтуючись на відповіді більшої частини викладачів $(77,88 \%)$, ми можемо зробити висновок, що у студентів усіх закладів вищої освіти, які навчаються на факультетах

(C) Ernest Ivashkevych, Ruslan Simko 
іноземної філологї̈, є можливості для становлення готовності до виконання профресійної діяльності, а також про те, що всі викладачі готові створити індивідуальну для кожного студента атмосферу на заняттях.

Отже, було виокремлено три групи викладачів за самооцінкою власної діяльності з огляду на їх бажання створити творчу атмосферу на заняттях. Це - педагоги з високим рівнем самооцінки власної професійної діяльності, ситуативною (середньою) та низькою самооцінкою тощо.

1. Представники першої групи намагаються максимальною мірою стимулювати самоактуалізацію студентів, їх готовність до самостійного виконання перекладацької діяльності (такі відповіді, як «намагаюсь стимулювати ініціативу студентів», «завжди є бажання працювати в атмосфері свободи професійної діяльності», "усі мої завдання передбачають більшою мірою аналітичну й творчу роботу, яка має виконуватись самостійно» тощо).

2. Представники другої групи (із ситуативною самооцінкою) прагнуть до стимулювання студентів лише за умови наявності можливостей і неабиякої наполегливості з боку студентів (наприклад: «я заохочую бажання студентів працювати самостійно, але в цій навчальній групі вони індивідуально працювати не бажають» або «зміст дисципліни, яку я викладаю, - надзвичайно важкий, тому студенти просто не можуть працювати самостійно»).

3. До третьої групи ми віднесли викладачів із низьким рівнем самооцінки власної професійної діяльності. Для них характерні такі відповіді, як: «для індивідуалізації навчання досить мало часу», «навчальний курс не передбачає виконання самостійних творчих завдань», «студенти не здатні на це», "у навчальних планах самостійна робота займає окреме місце, години не входять до картки навчального навантаження» .

Нами виявлено, що викладачі різних дисциплін досить по-різному ставляться до прагнення студентів до саморе- 
алізації і виконання самостійної діяльності у процесі навчання, зокрема:

- Викладачі спеціальних філологічних дисциплін:

○ 45,16\% викладачів повідомили про те, що «не всі студенти бажають самостійно виконувати професійну діяльність, але тих, хто прагне до самостійного виконання завдань із перекладу - достатньо, і вони «ведуть» за собою інших членів групи»;

○ $29,17 \%$ викладачів вважають, що «всі студенти факультету іноземної філології здатні та намагаються підійти до навчального процесу з інтересом, великим бажанням тощо та готові до виконання професійної діяльності»;

○ тільки $25,67 \%$ респондентів скептично налаштовані щодо готовності студентів до виконання професійної діяльності на своїх заняттях і вважають, що «мало хто на це взагалі здатен» .

- Викладачі загальних дисциплін (психолого-педагогічного циклу):

○ 26,18\% викладачів вважають, що «всі студенти бажають працювати самостійно і саме така діяльність для них є надзвичайно цікавою» ;

○ $73,82 \%$ викладачів зазначають, що «лише деякі студенти здатні самостійно виконувати індивідуальні науково-дослідні завдання» .

- Викладачі дисциплін обов'язкового циклу, тобто предметів, що безпосередньо не стосуються виконання студентами перекладацької діяльності (зокрема, дисципліни «Охорона безпеки життєдіяльності», «Філософія науки» тощо):

○ 52,43\% викладачів вважають, що студенти «здатні індивідуально розв’ язувати запропоновані задачі» ;

○ 47,57\% зауважують, що «студенти можуть лише репродуктивно відтворювати навчальний матеріал» .

Отримані результати свідчать про те, що у викладачів є всі можливості для роботи зі студентами в цьому напрямку, а саме: враховуючи налаштованість більшості студен- 
тів на індивідуальний підхід у навчанні - використовувати його для розвитку особистості студентів, становлення їх готовності до виконання професійної діяльності.

Усвідомлення студентами необхідності актуалізації та реалізації своїх здібностей у плані виконання перекладацької діяльності розраховувалось за сумою позитивних i негативних відповідей на запропоновані нами запитання інтерв'ю. Так, третина студентів кожної групи дала негативну відповідь. Проте, такий стан речей може бути пов'язаний із бажанням відійти від звичних, шаблонних відповідей, бажанням звернути на себе увагу й оригінально обгрунтувати свою точку зору. Тим не менш, більшість студентів у всіх групах підтверджують необхідність самоактуалізації. Порівняння результатів методом $\varphi$-критерію Фішера не показало значущих відмінностей (F = 0,73 в E1; $\mathrm{F}=0,71$ в $\mathrm{E} 2 ; \mathrm{F}=0,68$ в $\mathrm{E} 3 ; \mathrm{F}=0,67$ в $\mathrm{E} 1 ; \mathrm{F}=0,75$ у $\mathrm{K} 1$; $\mathrm{F}=0,69$ у $\mathrm{K} 2 ; \mathrm{F}=0,74$ у $\mathrm{K} 3 ; \mathrm{F}=0,73$ у $\mathrm{K} 4$ ) між студентами експериментальних і контрольних груп.

Коли ми запитали студентів, які у навчальній діяльності, як правило, не демонструють здатності до самоактуалізації, у чому причина такого становища, то $20,44 \%$ респондентів групи Е1, 21,32\% - E2, 31,44\% - E3, 32,82\% $\mathrm{E} 4,25,46 \%-\mathrm{K} 1,28,04 \%$ - К2, 21,02\%, - К3 та 28,44\% К4 з деякою образою відповіли, що викладачі, переважно, слухають те, що студенти хочуть висловити з певного питання, але не стимулюють їх до самостійності й активності. Крім того, майже половина студентів кожної групи говорили під час інтерв'ю, що лише деякі викладачі заохочують їх ініціативу, але уточнюють: «залежно від навчальної дисципліни». Понад 60\% студентів усіх груп зазначали, що прагнення до дискусій, які призводять до відхилення від теми, та звернення до тих питань, що їх дійсно цікавлять, а також прояви ініціативи на заняттях заохочуються досить рідко. Близько $20 \%$ студентів кожної групи на це запитання відповіли: «Викладачі частіше ігнорують ініціативу, ніж заохочують», що, в принципі, також не фаси- 
літує становлення готовності студентів до виконання професійної діяльності.

\section{Висновки}

Можна стверджувати, що розуміння викладачами закладів вищої освіти готовності студентів до виконання професійної діяльності, а також можливостей виконання студентами індивідуальної навчальної діяльності може залежати і від специфіки дисципліни. Тим не менш, спираючись на отримані дані, ми можемо зробити висновки, що близько половини викладачів (від 40\% до 60\% ) позитивно ставляться до можливостей, здібностей і здатностей студентів. 3 іншого боку, на думку викладачів, досить суттєвим є відсоток студентів (від $15 \%$ до $40 \%$ ), які на заняттях здатні лише на діяльність, наближену до репродуктивної. Отже, студенти впродовж навчальних занять із різних дисциплін перебувають у рівних умовах у плані стимулювання викладачами їх готовності до виконання професійної діяльності. Порівняння результатів за допомогою $\varphi$-критерію Фішера не показало значущих відмінностей між студентами експериментальних і контрольних груп. Тому отримані результати свідчать про те, що мікроклімат на факультетах іноземної філології в різних закладах вищої освіти загалом є сприятливим для прояву студентами активності й ініціативності та розкриття себе як творчого суб'єкта перекладацької діяльності.

\section{Література}

Библер В. С. На гранях логики культуры. Москва : Политиздат, 1997. $440 \mathrm{c}$.

Битянова Н. Р. Психология личностного роста. Москва : Междунар. пед. акад., 1995. 64 с.

Бондаренко А. Ф. Психологическая помощь: теория и практика [Электронный ресурс]. Киев : Укртехпрес, 1997.216 с. Режим доступа : http://lib.mdpu.org.ua/load/psihologiya/bondarenko_psihologicheskaya_pomosch_teoriya_praktika.pdf.

Варбан М. Ю. Рефлексия профессионального становления в студенческие годы: дис. ... канд. психол. наук: 19.00.01. Самара, 1998. 181 с.

(C) Ernest Ivashkevych, Ruslan Simko 
Зеер Э. Ф. Психология профессий [Электронный ресурс]. 2008. Режим доступа : https://studfiles.net/preview/1744899/.

Івашкевич Е. 3. Сенситивність та соціальна уява як фуркаційні чинники становлення соціального інтелекту педагога. Освіта регіону: Політологія. Психологія. Колунікацї. Украӥнський науковий журнал. Київ : Ун-т «Україна», 2015. № 1 (38). С. 118-124.

Кун М., Макпартленд Т. Тест «Кто Я?» [Электронный ресурс]. 2017. Режим доступа: vsetesti.ru/424.

Максименко С. Д. Розвиток особистості - розгортання чи новоутворення? Від самопізнання - до своєї професії. Шкільний світ. Психолог. 2005. № 1. С. 15-18.

Михальчук Н. О., Примачок Л. Л. Теоретико-методологічні засади становлення професійної рефлексії майбутніх фахівців [Електронний ресурс]. Сучасні проблели герланського та роланського ловознавства: Матеріали IV Міжнародної науково-практичної заочної конферениї (15 лютого 2019 р.). Рівне : РДГУ, 2019. С. 14-46. Режим доступу : https://sites.google.com/view/pam-rshu.

Онуфрієва Л. А. Формування професіоналізму і психологічна підготовка майбутніх фахівців соціономічних професій. Вісник Харківського національного університету ілені В. Н. Каразіна. Серія «Психологія». Харків : Харківський національний університет імені В. Н. Каразіна, 2013. № 1046. Вип. 51. С. 161-165.

Онуфрієва Л. А. Формування психологічної готовності випускників педагогічних спеціальностей ВНЗ до професійної діяльності. Проблели сучасної психологї: зб. наук. праць Кал'янець-Подільського національного університету ілені Івана Огієнка, Інституту психологї ілені Г. С. Костюка НАПН України / За наук. ред. С. Д. Максименка, Л. А. Онуфрієвої. Кам'янець-Подільський : Аксіома, 2011. Вип. 13. С. 185-195.

Пов'якель Н. І. Характеристика Я-концепції як чинника продуктивності саморегуляції професійного мислення у вирішенні конфліктів. Актуальні проблели психологї. Тол 1. Соціальна психологія. Психологія управління. Організаційна психологія: Збірник наук. праць Інституту психологї іл. Г. С. Костюка НАПН України / За ред. С. Д. Максименка, Л. М. Карамушки. Київ : Міленіум, 2003. Ч. 10. С. $43-47$.

Сластенин В. А. Формирование личности учителя советской школы в процессе профессиональной подготовки. Москва : Просвещение, 1976. $160 \mathrm{c}$.

Філоненко М. М. Психологія особистісного становлення майбутнього лікаря: автореф. ... д-ра психол. наук: 19.00.07. Київ : Ін-т психології імені Г. С. Костюка НАПН України, 2016. 40 с.

Хок Р. 40 исследований, которые потрясли психологию. Санкт-Петербург : Прайм-ЕВРОЗНАК, 2006. 509 с. 
Onufriieva, L. A. (2017). The Psychology of Professional Realization of a Future Specialist's Personality: Theoretical and Methodological Aspect. Monograph. Rzeszów : BonusLiber. $194 \mathrm{~s}$.

\section{References}

Bibler, V. S. (1997). Na granjah logiki kul'tury [On the verge of the logic of culture]. Moskva : Politizdat [in Russian].

Bitjanova, N. R. (1995). Psihologija lichnostnogo rosta [Psychology of personal growth]. Moskva : Mezhdunar. ped. akad. [in Russian].

Bondarenko, A. F. (1997). Psihologicheskaja pomoshch': teorija i praktika [Psychological assistance: theory and practice]. Kiev : Ukrtehpres Retrieved from http://lib.mdpu.org.ua/load/psihologiya/bondarenko_psihologicheskaya_pomosch_teoriya_praktika.pdf [in Russian].

Varban, M. Ju. (1998). Refleksija professional'nogo stanovlenija v studencheskie gody [Reflection of the professional development in students' years]. Candidate's thesis. Samara [in Russian].

Zeer, E. F. (2008). Psihologija professij [Psychology of the professions]. Retrieved from https://studfiles.net/preview/1744899/ [in Russian].

Ivashkevych, E. Z. (2015). Sensytyvnist ta sotsialna uiava yak furkatsiini chynnyky stanovlennia sotsialnoho intelektu pedahoha [Sensitivity and social imagination as furractic factors in the process of the development of social intelligence of a teacher]. Osvita rehionu: Politolohiia. Psykholohiia. Komunikatsii. Ukrainskyi naukovyi zhurnal-Education in the region: Politics. Psychology. Communications. Ukrainian Scientific Journal, 1 (38), 118-124. Kyiv : Universytet "Ukraina» [in Ukrainian].

Kuhn, M., \& McPartland, T. (2017). Test «Kto Ja?» [Test «Who am I?»]. Retrieved from https://vsetesti.ru/424 [in Russian].

Maksymenko, S. D. (2005). Rozvytok osobystosti - rozhortannia chy novoutvorennia? Vid samopiznannia - do svoiei profesii [The development of the personality - deployment or new formation? From selfknowledge - to his / her profession]. Shkilnyi svit. Psykholoh-School world. Psychologist, 1, 15-18 [in Ukrainian].

Mykhalchuk, N. O., \& Prymachok, L. L. (2019). Teoretyko-metodolohichni zasady stanovlennia profesiinoi refleksii maibutnikh fakhivtsiv [Theoretical and methodological principles of the development of professional reflection of future specialists]. Suchasni problemy hermanskoho ta romanskoho movoznavstva: Materialy IV Mizhnarodnoi naukovo-praktychnoi zaochnoi konferentsii (15 liutoho 2019 r.) - Contemporary Problems of Germanic and Romanic Linguistics: Proceedings of the Fourth International Scientific and Practical Distance Conference. Pivne : RDHU. Retrieved from https://sites. google.com/view/pam-rshu [in Ukrainian]. 
Onufriieva, L. A. (2013). Formuvannia profesionalizmu i psykholohichna pidhotovka maibutnikh fakhivtsiv sotsionomichnykh profesii [The development of professionalism and psychological training of future specialists of sociological professions]. Visnyk Kharkivskoho natsionalnoho universytetu imeni V. N. Karazina - Bulletin of V. N. Karazin Kharkiv National University. The series "Psychology», 1046 (51), 161-165. Kharkiv : Kharkivskyi natsionalnyi universytet imeni V. N. Karazina [in Ukrainian].

Onufriieva, L. A. (2011). Formuvannia psykholohichnoi hotovnosti vypusknykiv pedahohichnykh spetsialnostei VNZ do profesiinoi diialnosti [The development of psychological readiness of graduates of pedagogical specialties of higher educational institutions for professional activites]. Problemy suchasnoi psykholohii: zb. nauk. prats Kamianets-Podilskoho natsionalnoho universytetu imeni Ivana Ohiienka, Instytutu psykholohii imeni H. S. Kostiuka NAPN Ukrainy Problems of Modern Psychology. Collection of research papers of Kamianets-Podilskyi National Ivan Ohiienko University, G. S. Kos tiuk Institute of Psychology of the National Academy of Educational Sciences of Ukraine, 13, 185-195. Kamianets-Podilskyi : Aksioma [in Ukrainian].

Poviakel, N. I. (2003). Kharakterystyka Ya-kontseptsii yak chynnyka produktyvnosti samorehuliatsii profesiinoho myslennia $u$ vyrishenni konfliktiv [Characteristics of Me-concept as a factor of the productivity of self-regulation of professional thinking in the process of conflicts solving]. S. D. Maksymenko, L. M. Karamushka (Eds.). Aktualni problemy psykholohii. Sotsialna psykholohiia. Psykholohiia upravlinnia. Orhanizatsiina psykholohiia: Zbirnyk nauk. prats Instytutu psykholohii im. H. S. Kostiuka NAPN Ukrainy-Actual problems of Psychology. Social Psychology. Psychology of Management. Organizational Psychology: Collection of research papers of G. S. Kostiuk Institute of Psychology of NAPS of Ukraine, 1, Ch. 10, 43-47. Kyiv : Millennium [in Ukrainian].

Slastenin, V. A. (1976). Formirovanie lichnosti uchitelja sovetskoj shkoly $v$ processe professional'noj podgotovki [The development of a teacher's personality of the Soviet school in the process of professional training]. Moskva : Prosveshchenie [in Russian].

Filonenko, M. M. (2016). Psykholohiia osobystisnoho stanovlennia maibutnoho likaria [Psychology of the personal development of a future doctor]. Extended abstract of Doctor's thesis. Kyiv : In-t psykholohii imeni H. S. Kostiuka NAPN Ukrainy [in Ukrainian].

Hawk, R. (2006). 40 issledovanij, kotorye potrjasli psihologiju [ 40 researches that rocked psychology]. Sankt-Peterburg : Prajm-Evroznak [in Russian]. 
Onufriieva, L. A. (2017). The Psychology of Professional Realization of a Future Specialist's Personality: Theoretical and Methodological Aspect. Rzeszów : BonusLiber.

Івашкевич Ернест, Сімко Руслан. Самоактуалізація як чинник формування готовності студентів філологічних спеціальностей до виконання професійної діяльності

\section{АНОТАЦІЯ}

У статmі розглянуто професійне становлення майбутнього перекладача з позицій культурологічного підходу - як процес формування особистісно-професійної позиції індивіда з урахуванням усього різноманіття суб'єктивних і об'єктивних чинників, що передбачає реалізацію стратегій управління особистісними ресурсами, потрібними для здійснення професійної діяльності на фраховому рівні. Зазначено, шо професійне становлення майбутнього перекладача також передбачає формування особистісно значущої позиції, яка розуміється нами як система домінуючих ціннісно-смислових ставлень фахівця до сочіокультурного оточення, самого себе і своєї діяльності.

За критерії професійного становлення майбутніх перекладачів було прийнято високий рівень готовності студентів до виконання перекладацької діяльності, високий рівень сформованості професійної компетентності та перекладацької свідомості тощо.

Орієнтуючись на відповіді більщої частини викладачів, у статmі зроблено висновок, що у студентів усіх закладів вищої освіти, які навчаються на фракультетах іноземної філології, є можливості для становлення готовності до виконання професійної діяльності, а також про те, що всі викладачі готові створити індивідуальну для кожного студента атмосферу на заняттях.

Отже, було виокремлено три групи викладачів за самооцінкою власної діяльності з огляду на їхнє бажання створити творчу атмосферу на заняттях. Це - педагоги з високим рівнем самооцінки власної професійної діяльності, ситуативною (середньою) та низькою самооцінкою. Зазначено, що представники першої групи намагаються максимальною мірою стимулювати самоактуалізацію студентів, їх готовність до самостійного виконання перекладацької діяльності (такі відповіді, як «намагаюсь стимулювати ініціативу студентів», «завжди $\epsilon$ бажання працювати в атмосфері свободи професійної діяльності», «усі мої завдання передбачають більшою мірою аналітичну й творчу роботу, яка має виконуватись самостійно» тощо). Представники дру-

(C) Ernest Ivashkevych, Ruslan Simko 

гої групи (із ситуативною самооцінкою) прагнуть до стимулювання студентів лише за умови наявності можливостей і неабиякої наполегливості з боку студентів (наприклад: «я заохочую бажання студентів працювати самостійно, але в цій навчальній групі вони індивідуально працювати не бажають» або "зміст дисципліни, яку я викладаю, надзвичайно важкий, тому студенти просто не можуть працювати самостійно»). До третьої групи було віднесено викладачів із низьким рівнем самоочінки власної професійної діяльності. Для них характерні такі відповіді, як: "для індивідуалізації навчання досить мало часу», «навчальний курс не передбачає виконання самостійних творчих завдань", "студенти не здатні на це», "у навчальних планах самостійна робота займає окреме місце, години не входять до картки навчального навантаження».

Ключові слова: професійне становлення, культурологічний підхід, особистісно-професійна позиція індивіда, професійна компетентність, перекладацька свідомість, самоочінка професійної діяльності.

\section{Ивашкевич Эрнест, Симко Руслан. Самоактуализация как фактор формирования готовности студентов филологических специаль- ностей к выполнению профессиональной деятельности}

\section{АННОТАЦИЯ}

В статье рассмотрено профессиональное становление будущего переводчика с позиций культурологического подхода - как процесс формирования личностно-профессиональной позиции индивида с учетом всего многообразия субъективных и объективных факторов, который предусматривает реализацию стратегий управления личностными ресурсами, необходимыми для осуществления профессиональной деятельности на профессиональном уровне. Отмечено, что профессиональное становление будущего переводчика также предусматривает формирование личностно значимой позиции, которая понимается как система доминирующих ценностно-смысловых отношений специалиста к социокультурному окружению, к самому себе и своей деятельHости.

В качестве критериев профессионального становления будущих переводчиков было принято высокий уровень готовности студентов к выполнению переводческой деятельности, высокий уровень сформированности профессиональной компетентности и переводческого сознания. 
Ориентируясь на ответы больщей части преподавателей, в статье сделан вывод, что у студентов всех высших учебных заведений факультетов иностранной филологии есть возможности для становления готовности к выполнению профессиональной деятельности, $а$ также о том, что все преподаватели готовы создать индивидуальную для каждого студента атмосферу на занятиях.

Таким образом, было выделено три группы преподавателей по самооценке собственной деятельности с учетом их желания создать творческую атмосферу на занятиях. Это - педагоги с высоким уровнем самооценки собственной профессиональной деятельности, ситуативной (средней) и низкой самооценкой. Отмечено, что представители первой группы пытаются в максимальной степени стимулировать самоактуализацию студентов, их готовность к самостоятельному выполнению переводческой деятельности (такие ответы педагогов, как "стараюсь стимулировать инициативу студентов", "всегда есть желание работать в атмосфере свободы профессиональной деятельности", "все мои задачи предусматривают в большей степени аналитическую и творческую работу, которая должна выполняться самостоятельно»). Представители второй группы (с ситуативной самооценкой) стремятся к стимулированию студентов только с учетом незаурядной настойчивости со стороны студентов (например: "я актуализирую желание студентов работать самостоятельно, но в этой учебной группе они индивидуально работать не хотят» или «содержание дисциплины, которую я преподаю, - достаточно тяжелое, поэтому студенты просто не могут работать самостоятельно»). $K$ третьей группе были отнесены преподаватели с низким уровнем самооценки собственной профессиональной деятельности. Для них характерны такие ответы, как: "для индивидуализации обучения достаточно мало времени», "учебный курс не предусматривает самостоятельного решения творческих задач», "студенты не способны на индивидуальное обучение», "в учебных планах самостоятельная работа занимает отдельное место, часы не входят в карточку учебной нагрузки».

Ключевые слова: профессиональное становление, культурологический подход, личностно-профессиональная позиция индивида, профессиональная компетентность, переводческое сознание, самооценка профессиональной деятельности. 